\title{
Tree Mortality following Prescribed Fire and a Storm Surge Event in Slash Pine (Pinus elliottii var. densa) Forests in the Florida Keys, USA
}

\author{
Jay P. Sah, ${ }^{1}$ Michael S. Ross, ${ }^{1,2}$ James R. Snyder, ${ }^{3}$ and Danielle E. Ogurcak ${ }^{2}$ \\ ${ }^{1}$ Southeast Environmental Research Center (SERC), Florida International University, University Park, Miami, FL 33199, USA \\ ${ }^{2}$ Department of Earth and Environment, Florida International University, Miami, FL 33199, USA \\ ${ }^{3}$ US Geological Survey, Florida Integrated Science Center, Ochopee, FL 34141, USA
}

Correspondence should be addressed to Jay P. Sah, sahj@fiu.edu

Received 29 July 2009; Revised 7 December 2009; Accepted 16 December 2009

Academic Editor: Hamish Kimmins

Copyright () 2010 Jay P. Sah et al. This is an open access article distributed under the Creative Commons Attribution License, which permits unrestricted use, distribution, and reproduction in any medium, provided the original work is properly cited.

\begin{abstract}
In fire-dependent forests, managers are interested in predicting the consequences of prescribed burning on postfire tree mortality. We examined the effects of prescribed fire on tree mortality in Florida Keys pine forests, using a factorial design with understory type, season, and year of burn as factors. We also used logistic regression to model the effects of burn season, fire severity, and tree dimensions on individual tree mortality. Despite limited statistical power due to problems in carrying out the full suite of planned experimental burns, associations with tree and fire variables were observed. Post-fire pine tree mortality was negatively correlated with tree size and positively correlated with char height and percent crown scorch. Unlike post-fire mortality, tree mortality associated with storm surge from Hurricane Wilma was greater in the large size classes. Due to their influence on population structure and fuel dynamics, the size-selective mortality patterns following fire and storm surge have practical importance for using fire as a management tool in Florida Keys pinelands in the future, particularly when the threats to their continued existence from tropical storms and sea level rise are expected to increase.
\end{abstract}

\section{Introduction}

In fire-dependent plant communities, such as pine (Pinus spp.) forests, prescribed fire is an efficient tool to reduce fuel loads, control the growth of hardwood species, promote pine regeneration, and restore diversity in the ground layer herbaceous community [1-3]. Prescribed fire is commonly practiced in South Florida pine rocklands, which is an imperiled ecosystem, and important for preservation of endemic plants and endangered wildlife, such as Key Deer (Odocoileus virginianus clavium). Predicting post-fire pine tree mortality is needed for effective use of prescribed fire in the pine forests, since pine mortality may alter fuel dynamics, destroy the live seed source necessary for pine regeneration, and affect ecosystem processes, altering plant population and community structure [4].

Models that predict post-fire tree mortality have been developed for a number of North American tree species
[5-8]. However, only a few studies have described post-fire mortality of South Florida slash pine $[9,10]$, and predictive models for post-fire slash pine mortality in the Florida Keys pine forests are not available. Moreover, studies of postfire tree mortality are generally based on observations made only during the first year after fire, though delayed mortality in subsequent years may also be important [11]. Delayed mortality is a common phenomenon in South Florida pine forests where insect outbreaks and hurricane-related wind damage usually increase the probability of pine mortality after fire $[10,12]$. In the Florida Keys, pine forests are found at low-elevation coastal settings where freshwater is present in a shallow groundwater lens, and the forests are occasionally flooded by storm surge that kills salt-sensitive pine trees [13]. Hence, an assessment of the interacting effects of fire and other disturbances on slash pine mortality is important for development and implementation of any fire management plan in Florida Keys pine forests. 
Post-fire mortality depends on tree morphology and physiology and fire behavior. Tree species differ in their susceptibility to fire, and even within species, trees at different growth stages vary in response. Likewise, fire intensity also influences tree mortality. Therefore, models that predict post-fire mortality usually include tree attributes and apparent fire damage characteristics as independent variables. The most commonly used tree attributes are diameter at breast height (DBH) and bark thickness, which may be interactive in their effects. Bark thickness protects the cambium by increasing its resistance to injury from fire $[5,14]$. At the same time, bark thickness is often positively correlated with DBH [15]. For species in which DBH and tree height are strongly correlated, DBH can also reflect crown susceptibility to scorching, though such relationships depend on fire history, stand structure, and the specific burn $[16,17]$.

Fire damage measurements in trees include the extent of tissue damage in their various parts, including roots, stems, crown leaves, and buds [7]. Fire damage to fine roots of trees can be crucial for their post-fire survival. Although ground surface burn severity is often used as a proxy of root damage [18], the severity may not always reflect the extent of damage, especially when fire is reintroduced after a long period of fire suppression in systems dependent on frequent fire [19]. Stem damage and crown damage are commonly used as surrogate measures of fire intensity and also as predictors of post-fire tree mortality. Measures of stem damage include bole char height, bole char depth, bark char ratio, and visible cambium injury. Among them, bole char height has been widely used either alone or in combination with crown damage to predict tree mortality after fire $[9,17,18]$. Char height sometimes is preferable to measures of crown scorch because of its permanence, ease of collection, and strong correlation with fire intensity. In several conifer forests, however, and percent crown scorch, expressed in terms of a number of variables, such as crown scorch height, percent crown scorch volume, and so forth, has also been used to predict post-fire tree mortality [7]. While crown scorch height represents fire intensity well, post-fire tree mortality is more directly related to crown scorch volume [20, 21].

In the Florida Keys, both coastal and upland ecosystems, including pine forests, are vulnerable to hurricane-associated winds and storm surge. Slash pine mortality due to wind damage depends on hurricane intensity and stand age. Large trees in old-growth stands are more likely to be killed than small trees or those in second-growth stands [12]. While tree mortality from wind damage is a mechanical phenomenon, storm surge-induced mortality is physiologically based, resulting from flooding and salinity stress. Response of nonhalophytic plants to these stresses depends on species, flooding duration, salinity, and plant growth stage [22].

In this study, we examined the effects of prescribed fire and a storm surge event on tree mortality in Florida Keys pine forests. Our objectives were twofold, (i) to develop a model to predict the probability of post-fire mortality of slash pine in Florida Keys pine forests as a function of burn season, tree size and fire characteristics, and (ii) to examine the effects of storm surge events on pine tree mortality. We expected higher tree mortality following summer, growing season burns than winter, dormant season fires. We also hypothesized that post-fire slash pine mortality would be negatively correlated with tree size, and positively with fire intensity expressed in terms of stem and crown damage. Slash pine mortality was also expected to be higher in stormsurge impacted burned plots than in unimpacted burned and unburned plots.

\section{Materials and Methods}

2.1. Study Area. The study area is located in the National Key Deer Refuge (NKDR) in the Lower Florida Keys (Figure 1). Pine forests in the Florida Keys are characterized by a canopy of South Florida slash pine (Pinus elliottii var. densa), a diverse understory dominated by West Indian tropical hardwoods and several palm species, and a diverse herb layer [23]. In this forest, fire usually improves Key Deer habitat by preventing succession towards a dense hardwood community [24]. Currently, less than 1000 ha of Lower Keys pinelands are scattered over seven islands, where lowelevation pine forests are occasionally flooded by salt waters associated with hurricane-induced storm surge. Our study focused on pine forests on Big Pine Key, which is the largest island in the Lower Florida Keys and contains the vast majority of Keys pine forest [13].

\subsection{Experimental Design. The study on pine mortality was} a part of an experiment carried out to characterize fuel loads to examine relationships among stand age, fuel load, and fire characteristics and to assess the effects of fire on pine and hardwood trees, understory shrubs and palms, and ground layer flora, including endemic species [2527]. The experimental design has been described in detail elsewhere $[25,26]$. In brief, the study site included 181 ha plots, established in six homogeneous blocks, each with three plots. The blocks were in one of two characteristic understory types: (i) a relatively sparse shrub layer (open), and (ii) a dense shrub layer (shrubby). Shrubby and open plots were chosen to represent different understory fuel conditions that would influence fire intensity. Moreover, since burning conditions and growth patterns of slash pine trees differ between rainy (summer) and winter seasons, the experimental design called for burns to be carried at two times of the year. Thus, the three plots in each block were randomly assigned to the three treatments: (1) summer burn, (2) winter burn, and (3) control, to be carried out during three consecutive years $(1998,1999$, and 2000). The 18 plots were identified by year of intended treatment, characteristic understory (open, shrubby), and treatment (summer burn, winter burn, control). For instance, the shrubby plot to be burned in the summer of 1998 was designated as 1998-S-S, and winter-burned plot in the same block was 1999-S-W.

Because of weather and logistic constraints, all experimental burns were not carried out as planned and only eleven of the 18 plots were burned under prescription during the study. Eight plots were burned during the early part of the rainy season (summer season), when lightning-caused fires are likely to occur $[28,29]$, and three plots were burned 


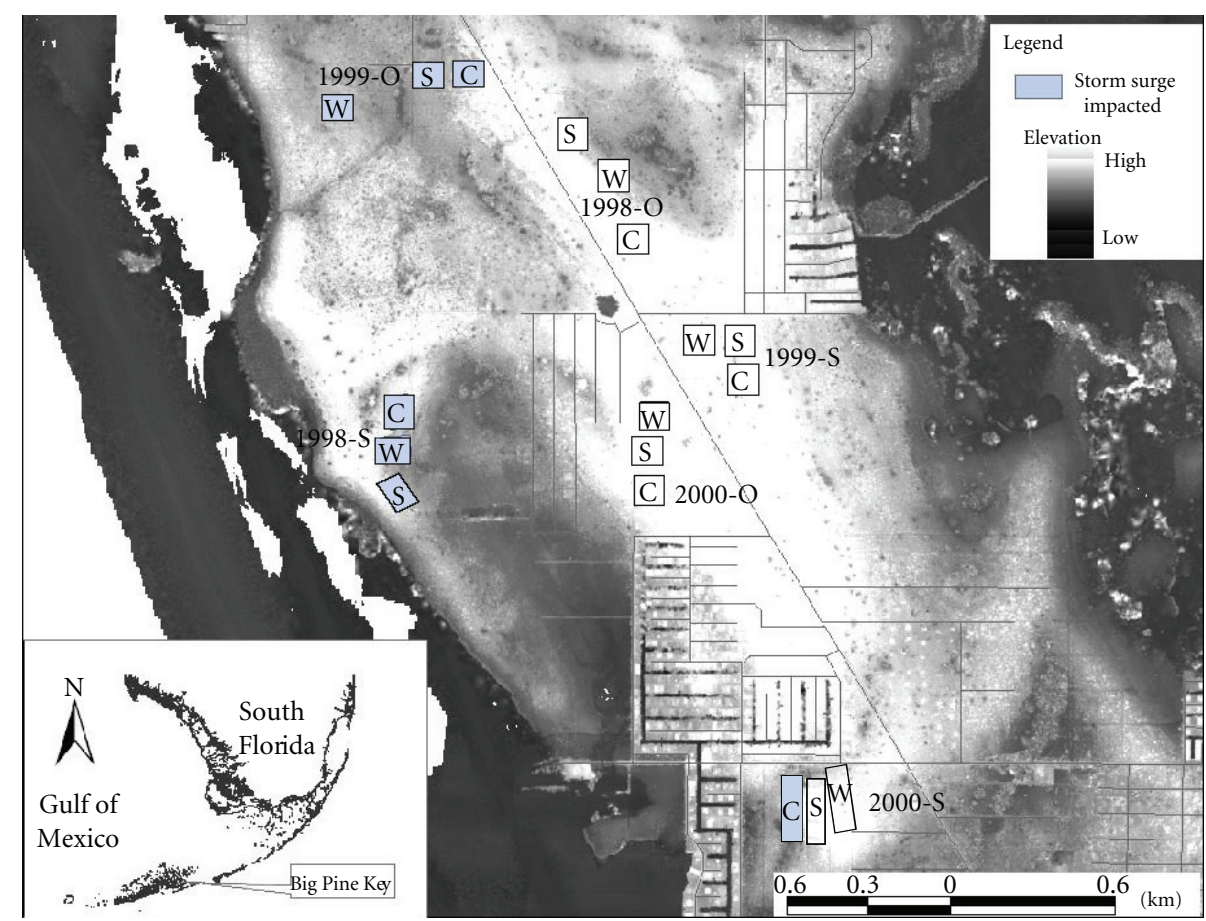

FIGURE 1: Study area map showing the layout of experimental plots. The background is the ground elevation (m) - the lighter the area, the higher the ground elevation-derived from LiDAR data.

during December/January (winter season), when plants were most dormant and burning conditions were relatively mild (Table 1). In 1998, the summer and winter burns in 1998$\mathrm{O}$ and 1998-S blocks burned on schedule. In 1999, only the summer burns were completed in the 1999-O and 1999-S blocks. The winter burn for the 1999-O block was completed a year late, in December 2000, and the 1999-S-W plot was never burned. In the summer of 2001, the summer and winter burn plots in both 2000-O and 2000-S blocks were burned.

In addition to the targeted experimental burns, 6 plots in two blocks, 1998-O and 1998-S, were burned by NKDR staff in 2004. Two plots, 1998-O-S and 1998-O-W, were only partially (50\% and 75\%, resp.) burned. In 2005, much of Big Pine Key was flooded by storm surge caused by Hurricane Wilma. Five burned and 2 unburned plots located in the low elevation $(<1 \mathrm{~m})$ area on the west side of the island were especially affected. The plots located on relatively high ground or in the northeast part of the island were either not flooded or flooded only modestly. Since none of the sites were sampled immediately prior to the hurricane, we could not distinguish between fire- and storm surge-caused tree mortality in plots that experienced both disturbances. Our analysis of only storm surge-caused tree mortality was therefore restricted to effects observed in unburned plots.

2.3. Fire Intensity, Char Height, and Percent Crown Scorch. Fire temperature, which is a direct measure of fire intensity, was not measured. Instead, we measured char height and percent crown scorch within one month after the fires in all burned plots. Char height, the maximum height of charring on the bole, was measured directly on individual trunks irrespective of direction [30]. Percent crown scorch (CVS, percent crown scorch volume, [7]), a measure of the amount of live needles killed by the fire, was estimated using the following scale: $0 \%, 10 \%, 25 \%, 50 \%, 75 \%, 90 \%$, and $100 \%$. There was essentially no needle consumption in any of the fires, mainly because fires were of low to medium intensity and the flames never reached the crowns of the trees.

2.4. Tree Measurements. All pine and hardwood trees ( $\geq 5 \mathrm{~cm} \mathrm{dbh}$ ) were tagged and their $\mathrm{DBH}$ was measured in the year when plots in a block were assigned to be burned. Post-fire pine mortality was investigated annually for three years in both summer and winter burns plots in the 1998$\mathrm{O}$ and 1998-S blocks, for two years in summer burn plots in the 1999-O and 1999-S blocks, and for one year in winter burn plot in the 1999-O Block (Table 1). Pine mortality was recorded also in the control plots of these four blocks. In two blocks, 2000-O and 2000-S, burned plots were only surveyed seven years after the prescribed burn, which took place in 2001. All burned and unburned plots were revisited in 2008, when the $\mathrm{DBH}$ of all trees was remeasured.

2.5. Statistical Analysis. We analyzed differences in tree characteristic and post-fire percent pine tree mortality among 


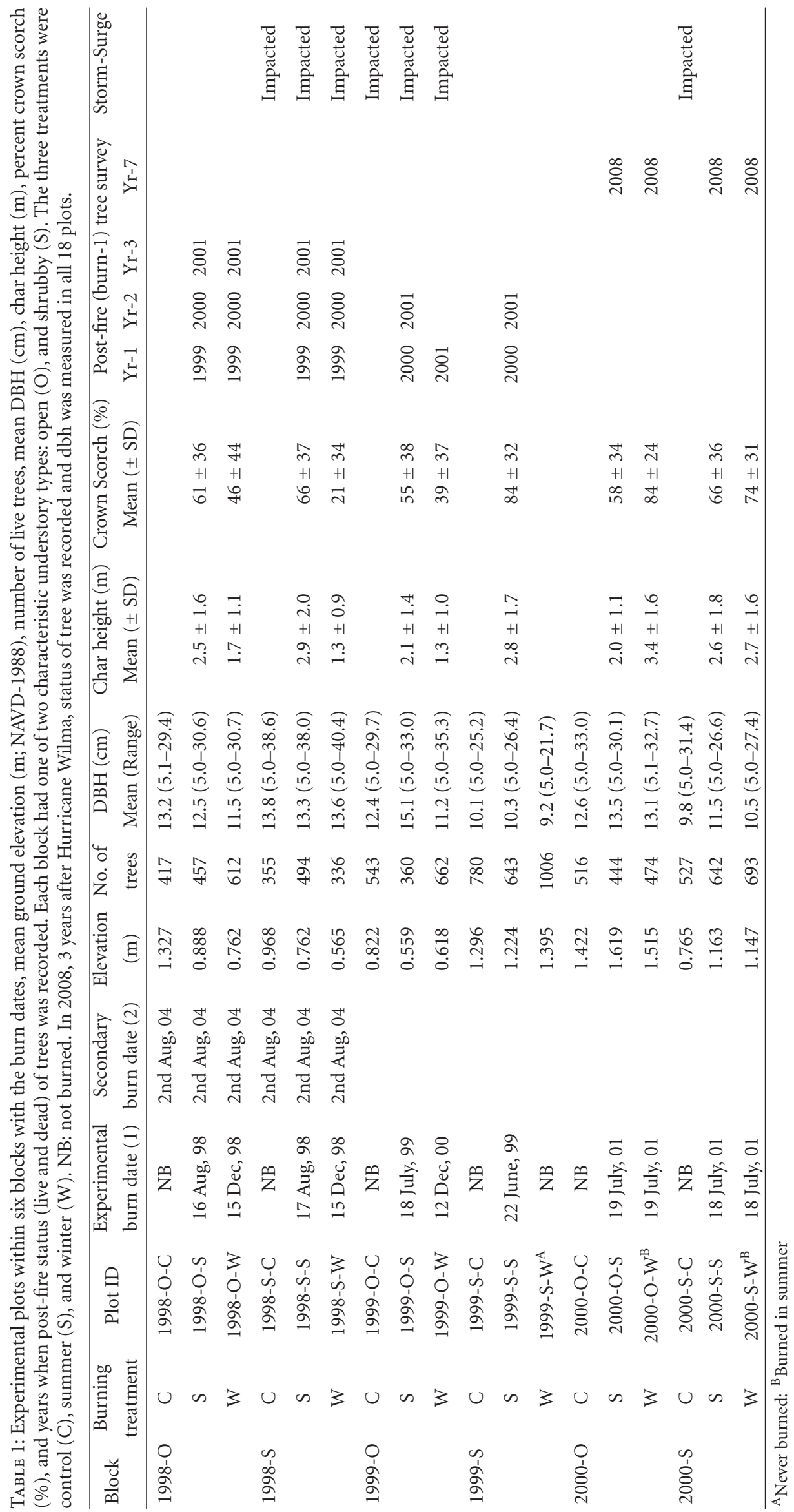


different levels of understory conditions (U: shrubby and open), burning treatments (T: control, summer burn and winter burn), and year (Y: 1998 and 1999) using threeway analysis of variance (ANOVA). Since the plots were not burned as planned resulting in an unbalanced design with a missing value, we used a General Linear Model (GLM). To stabilize within group variances, we transformed percent pine tree mortality data using an arcsine-square root transformation. In the model, understory conditions (U), burning treatments $(\mathrm{T})$, and their interaction $(\mathrm{U} * \mathrm{~T})$ were the fixed effects, and year $(\mathrm{Y})$ and its interactions $(\mathrm{Y} * \mathrm{U}$, $\mathrm{Y} * \mathrm{~T})$ were considered as random effects. The three-way interaction was not evaluated. Instead, it was used as the mean square (MS) error to test the first-order interaction effects. Since complete records of post-fire pine tree mortality in all plots burned between 1998 and 2000 were available for the first year after fire only, analysis of variance was restricted to the percent mortality within one year.

In burned plots, $\mathrm{DBH}$, char height and percent crown scorch within the groups compared were not normally distributed (Kolmogorov-Smirnov normality test; $P<.001$ ). We used Mann-Whitney's nonparametric U test to examine the differences in tree size and fire-induced damage characteristics between two groups of trees, live and dead. In addition, post-fire tree mortality models were developed using a binary logistic regression model of the following form:

$$
P(m)=\frac{1}{1+e^{-\left(\beta_{0}+\beta_{1} X_{1}+\cdots+\beta_{k} X_{k}\right)}},
$$

where $P_{(m)}=$ probability of post-fire mortality, $X_{1}, \ldots, X_{k}$ are independent variables, and $\beta_{0}, \beta_{1}, \ldots, \beta_{k}$ are the regression coefficients.

The models were developed to predict the probability of fire-induced pine tree mortality one year after fire in the plots burned in 1998, 1999, or 2000, and seven years after fire in the plots burned in 2001. We used season of burn $(\mathrm{S})$, tree size $(\mathrm{DBH})$, char height $(\mathrm{CH})$, and percent crown scorch (CVS) as independent variables to predict probability of slash pine mortality. An indicator variable with the values 1 and 0 for the summer and winter seasons, respectively, was created to represent the categorical variable Season of Burn. Since char height generally represents fire intensity well and is significantly related to preburn fuel loads in Florida Keys pine forest [26], a reduced model, including only DBH and char height as independent variables, was also developed. In addition, a reduced model with only percent crown scorch as the predictor variable was developed.

The merits of using the logistic model include the predictions of binary dependent variables, having a value of 0 or 1 , from continuous, nominal, or ordinal independent variables, and the data do not need to be normally distributed. Logistic regression models estimate the coefficients for the independent variables using a maximum likelihood process. We computed maximum likelihood estimates of model parameters and used Wald $\chi^{2}$ test statistic to assess the significance of individual parameters. Model performance was assessed using Receiver Operating Characteristic (ROC) curve analysis [21]. The ROC curve analysis is a method for assessing the performance of diagnostic decision making process, consisting of a stimulus and a response [31]. In evaluating tree mortality prediction models, the observed status of tree-live or dead-is the stimulus, and probability of mortality, scaled from 0 to 1 , is the response. In this method, the probability of a true positive prediction ("hit", i.e., a dead tree is classified as dead) versus the probability of a false positive prediction ("miss", e.g., a live tree is classified as dead) is plotted across the continuous probability of mortality cutoff ranges from 0 to 1 . In an ROC plot, concordance value, that is, the area under the curve (AUC) statistic (or the C-statistic) is used for evaluating the model performance. AUC varies between 0 and 1 , and the greater the AUC, the better the performance [21]. Although criteria for ROC value cut-off vary with types of error, models with ROC values $>0.9$ are considered outstanding, between 0.8 and 0.9 excellent, and between 0.7 and 0.8 acceptable in discrimination [31].

We developed a simple least square regression model to examine the effects of storm surge on percent tree mortality at the plot level. In the model, we used mean ground elevation as a surrogate measure of storm surge, based on the assumption that the impact of storm surge on standing trees would be inversely correlated with elevation. Plot level mean elevation was obtained from a digital terrain model (DTM) developed from LiDAR data by Robertson and Zhang [32]. The DTM was in the form of high-resolution $(1 \times 1 \mathrm{~m}$ grid $)$ raster map and had the vertical accuracy of $0.17 \mathrm{~m}$ at the $95 \%$ confidence interval.

Changes in stand structure in the plots were analyzed by comparing mean stand diameter and basal area measured in the beginning of experimental burns and in 2008. We calculated change in mean diameter and basal area for four groups of plots: (i) no burn and no storm surge (Unburn), (i) burned but no storm surge (Burned), (iii) no burn but storm surge (Unburn-SS), and (iv) burned and storm surge (Burned-SS), and used one-way analysis of variance (ANOVA) to examine among group differences. Finally, changes in tree size distribution were examined by fitting curves to the mean number of trees in a range of $\mathrm{dbh}$ classes in both surveys. Two curves were compared using the following $F$-statistic:

$$
F=\frac{\left(\mathrm{SS}_{C}-\mathrm{SS}_{I}\right) /\left(\mathrm{DF}_{C}-\mathrm{DF}_{I}\right)}{\mathrm{SS}_{I} / \mathrm{DF}_{I}}
$$

where $\mathrm{SS}_{I}$ and $\mathrm{DF}_{I}$ are total sums-of-squares and degrees of freedom, respectively, from each individual fit, and $\mathrm{SS}_{\mathrm{C}}$ and $\mathrm{DF}_{\mathrm{C}}$ are sum-of-squares and degrees of freedom from the combined data. We used SPSS version 17.0 (SPSS, Chicago, IL, USA) for logistic regression analysis, and STATISTICA ver. 7.0 (StatSoft) for all other statistical analyses and graphics.

\section{Results}

Pine tree mortality in Big Pine Key pine forests varied among plots, depending on whether the plots were burned or not, and/or were impacted by Hurricane Wilma. During the 
TABLe 2: $F$-statistic and $P$-value from a General Linear Model (GLM) used to test differences in mean percent pine mortality after one year of prescribed burns. The plot-level mean tree mortality data from 12 plots in four blocks (1998-O, 1999-S, 1999-O, and 1999-S) were used. The mortality data in the plot 1999-S-W were missing. In the model, understory conditions (U), burning treatments (T), and their interaction $(\mathrm{U} * \mathrm{~T})$ were the fixed effects, and year $(\mathrm{Y})$ and its interactions $(\mathrm{Y} * \mathrm{U}, \mathrm{Y} * \mathrm{~T})$ were the random effects. The three-way interaction $(\mathrm{U} * \mathrm{~T} * \mathrm{Y})$ was used as the mean square (MS) error for the interaction effects. Error terms for the fixed main effects, $\mathrm{U}$ and $\mathrm{T}$, were $\mathrm{U} * \mathrm{Y}$ and $\mathrm{T} * \mathrm{Y}$, respectively, and for the random effect, $\mathrm{Y}$, the error term was $\mathrm{MS}(\mathrm{U} * \mathrm{Y})+0.889 * \mathrm{MS}(\mathrm{T} * \mathrm{Y})-0.889 * \mathrm{MS}(\mathrm{error})$.

\begin{tabular}{lccc}
\hline Effects & df (effects, error) & $F$ & $P$-value \\
\hline Intercept & 1,1 & 269.90 & .039 \\
Understory (U) & 1,1 & 1.13 & .481 \\
Treatment (T) & 2,2 & 46.15 & .021 \\
Year (Y) & $1,0.08$ & .0 .23 & .907 \\
$\mathrm{U} * \mathrm{~T}$ & 2,1 & 1.08 & .562 \\
$\mathrm{U} * \mathrm{Y}$ & 1,1 & 1.18 & .473 \\
$\mathrm{~T} * \mathrm{Y}$ & 2,1 & 0.13 & .891 \\
\hline
\end{tabular}

TABle 3: Mean ( \pm 1 SD) tree size and fire damage characteristics of live and dead slash pine trees. The $P$-value shows results of Mann-Whitney U-tests between live and dead trees after one year of prescribed fire in seven plots burned between 1998 and 2000.

\begin{tabular}{lccc}
\hline & $\begin{array}{c}\text { Live } \\
(n=2,870)\end{array}$ & $\begin{array}{c}\text { Dead } \\
(n=680)\end{array}$ & $P$-value \\
\hline DBH $(\mathrm{cm})$ & $12.5 \pm 5.8$ & $10.6 \pm 5.6$ & $<.001$ \\
Char height $(\mathrm{m})$ & $1.80 \pm 1.38$ & $3.35 \pm 1.73$ & $<.001$ \\
Crown scorch $(\%)$ & $45.2 \pm 39.7$ & $95.5 \pm 17.0$ & $<.001$ \\
\hline
\end{tabular}

period 1998-2008, overall pine mortality ranged between $8.1 \%$ in $1999-S-C$ plot and $97.3 \%$ in $1999-O-W$ plot (Figure 2). In general, burned plots in each block had higher pine mortality than unburned plots in the same block, except in the 2000-S block, where the unburned control plot (2000-S-C) experienced high pine mortality following the 2005 storm surge event. In the other comparable, low elevation blocks (1998-S, 1999-O), plots that were burned and also impacted by storm surge had higher mortality than unburned and unimpacted burned plots.

In a forest that does not experience a catastrophic natural or anthropogenic disturbance, annual background tree mortality rate is assumed to be consistent over a given period. On Big Pine Key, three experimental plots, 1999-SC, 1999-S-W, and 2000-O-C, which neither burned during the 10-year study period nor were impacted by storm surge in 2005, had a background rate of pine tree mortality of less than $1.5 \%$ per year.

3.1. Tree Mortality from Fire. One year after fire, plot level mean pine mortality did not differ between open and shrubby understory conditions $(P=.481)$ and between 1998 and 1999 groups $(P=.907)$, but there was significant effect $(P=.021)$ of burn treatments (Table 2$)$. However, the post hoc test (Unequal N; Tukey's HSD) failed to detect significant differences among three treatments (control, summer, and burn), probably due to low power. A subsequent analysis (One-way ANOVA) on pooled data revealed that mean percent mortality $(0.81 \%)$ in control plots $(n=4)$ was significantly lower (Tukey's HSD, $P=.02$ ) than the mean mortality in summer burn $(n=4 ; 25.3 \%)$ but did not differ $(P=.116)$ from the mortality in winter burn $(n=3 ; 7.6 \%)$. Difference in one-year post-fire mean tree mortality between summer and winter burns was not statistically significant. In the three paired sets of summer and winter burns also, the difference between summer and winter burn plots was not significant (Wilcoxon Pair test; $P>.05$ ).

Before prescribed burn, plot level mean tree size (dbh) did not significantly differ between shrubby and open plots $(P=.169)$, among three burn treatments $(P=.578)$, control, summer, and winter burns, or between years $(P=$ $.10)$ in which plots were to be burned. After prescribed burn, however, fire-induced mortality of individual trees in burned plots was influenced by both tree size and immediate fire damage to trees. Over all burned plots, in which the trees were resurveyed after one year of fire, $\mathrm{DBH}$, char height, and percent crown scorch differed between dead and live trees (Mann-Whitney $U$ test: $P<.001$ ). Dead trees had smaller $\mathrm{DBH}$ and larger char height, and percent crown scorch than the live trees (Table 3). Individual plot-level tests (Mann-Whitney $U$-test) of significance for these three independent variables revealed that dead trees had larger percent crown scorch than live trees in all burned plots. $\mathrm{DBH}$ and char height also differed between live and dead trees in five of seven plots. However, in two plots, 1998-S-W and 1999-O-W, there were no significant differences in DBH and Char height between live and dead trees. Moreover, in four unburned plots, background tree mortality was uniform across all tree sizes.

Logistic regression results for tree mortality after one year of fire also revealed that the best predictive model included $\mathrm{DBH}$, char height, and percent crown scorch as predictive variables (Table 4$)$. The Likelihood Ratio $\left(\chi^{2}\right)$ statistic was highly significant $(P<.001)$ and the area under the ROC curve $(C)$ indicated $91.1 \%$ concordance between predicted probabilities and observed outcomes. Burn season, entered as a categorical variable in the model for three pairs of plots burned in summer and winter seasons, was not significant 
TABLE 4: 1- and 7-year post-fire tree mortality models for slash pine after prescribed burns carried out between 1998 and 2001 in Big Pine Key, Florida.

\begin{tabular}{|c|c|c|c|c|c|c|c|c|c|c|c|}
\hline \multirow{2}{*}{ Models } & \multirow{2}{*}{$n$} & \multicolumn{3}{|c|}{ Variables } & \multicolumn{4}{|c|}{ Coefficients } & \multirow{2}{*}{$\mathrm{H}-\mathrm{L}\left(\chi^{2}\right)$} & \multirow{2}{*}{$P$} & \multirow[t]{2}{*}{$\mathrm{C}$} \\
\hline & & $X_{1}$ & $X_{2}$ & $X_{3}$ & $\beta_{0}$ & $ß_{1}$ & $\beta_{2}$ & $B_{3}$ & & & \\
\hline \multicolumn{12}{|c|}{ 1-year post fire } \\
\hline 1 & 3523 & $\mathrm{DBH}$ & $\mathrm{CH}$ & CVS & $\begin{array}{c}-5.8901 \\
(0.4041)\end{array}$ & $\begin{array}{r}-0.1166 \\
(0.0133)\end{array}$ & $\begin{array}{c}0.5379 \\
(0.0407)\end{array}$ & $\begin{array}{c}0.0546 \\
(0.0041)\end{array}$ & 292.2 & .001 & 0.911 \\
\hline 2 & 3530 & $\mathrm{DBH}$ & $\mathrm{CH}$ & - & $\begin{array}{c}-1.2808 \\
(0.1212)\end{array}$ & $\begin{array}{c}-0.2105 \\
(0.0129)\end{array}$ & $\begin{array}{c}0.9168 \\
(0.0396)\end{array}$ & & 157.6 & .001 & 0.845 \\
\hline 3 & 3550 & CVS & - & - & $\begin{array}{c}-7.2966 \\
(0.4162)\end{array}$ & $\begin{array}{c}0.0720 \\
(0.0044)\end{array}$ & & & 444.8 & .001 & 0.888 \\
\hline \multicolumn{12}{|c|}{ 7-year post fire } \\
\hline 4 & 2227 & $\mathrm{DBH}$ & $\mathrm{CH}$ & CVS & $\begin{array}{r}-1.1753 \\
(0.1890)\end{array}$ & $\begin{array}{r}-0.1109 \\
(0.0117)\end{array}$ & $\begin{array}{c}0.3974 \\
(0.0363)\end{array}$ & $\begin{array}{c}0.0171 \\
(0.0018)\end{array}$ & 36.1 & .001 & 0.768 \\
\hline
\end{tabular}

$n$ : number of trees observed.

Standard error of constant and independent variable coefficients are given in the parenthesis with each coefficient value.

DBH: Diameter at breast height $(\mathrm{cm})$; CH: Char height $(\mathrm{m})$; CVS: Percent crown scorch (\%).

H-L $\left(\chi^{2}\right)$ : Hosmer and Lemeshow chi-square statistic for assessing goodness of fit.

$P$ : Statistical significance of Hosmer and Lemeshow $\left(\chi^{2}\right)$ test statistic.

$C$ : Concordance value which is equivalent to area under the curve in the receiver operations characteristic (ROC) curve analysis for assessing the performance of the model.

in predicting the probability of tree mortality. Likewise, the contribution of interaction terms between DBH and char height, and $\mathrm{DBH}$ and percent crown scorch did not improve the model. Test of model performance with and without these interaction terms was almost identical, as they increased the concordance value only by 0.001 . One year after burn, the probability of post-fire pine mortality decreases with increases in tree size and increases with increases in both char height and percent crown scorch (Table 4). Char height was the strongest predictor, as indicated by the highest odd ratio $(\operatorname{Exp} \beta)$ among all three predictors. A reduced model, including only char height and $\mathrm{DBH}$ as predictors of mortality, was also highly significant $\left(\chi^{2}=157.6 ; P \leq .001\right)$ and had an acceptable level of concordance $(C=.845)$. The response surface for probabilities of post-fire tree mortality as a function of $\mathrm{DBH}$ and char height revealed that the probability of tree mortality of similar DBH increased with increasing char height, and at the same fire intensity, the mortality risk decreased with increasing DBH (Figure 3). However, percent crown scorch always entered at the first step of the stepwise procedure, suggesting the importance of crown damage in predicting tree mortality. A simple logistic model with a single independent variable, percent crown scorch, was also significant $\left(\chi^{2}=444.8 ; P<.001\right)$ and had an acceptable level of concordance $(C=0.888)$. Probability of tree mortality increased exponentially when trees had $>80 \%$ of crown scorch (Figure 4).

In the four burned plots in which post-fire tree status was recorded for three consecutive years after fire, tree mortality significantly differed (One-way ANOVA; $F_{2,9}=23.2 ; P<$ .01 ) among years. There was over $15 \%$ tree mortality in the first year and an additional $1.53 \%$ and $0.87 \%$ in the second and third years, respectively (Figure 5). The fire-induced tree mortality was not significantly different (Tukey's HSD; $P=$ .973) between second and third years after fire. Moreover,

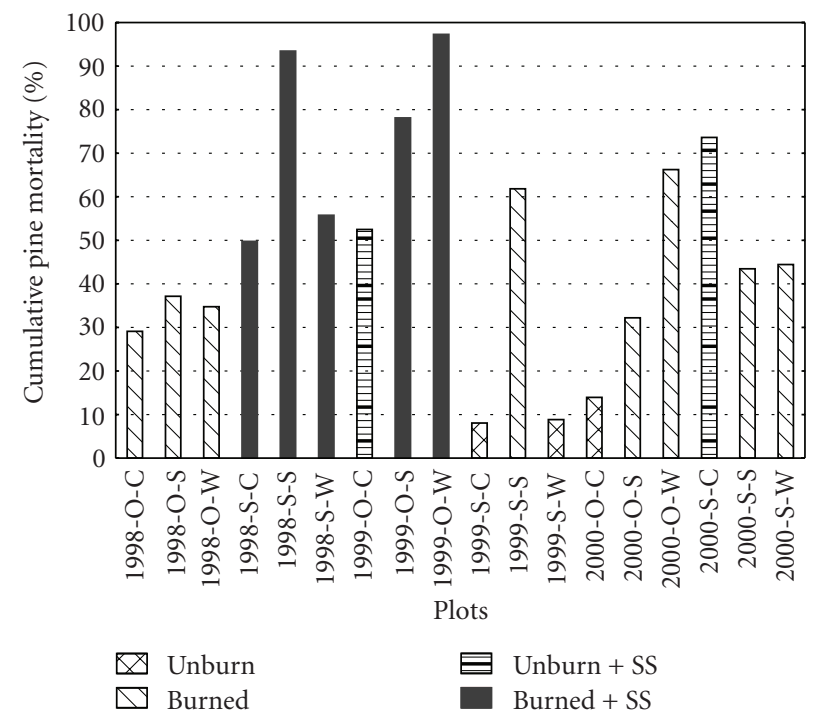

FIGURE 2: Total pine tree mortality in the 18 experimental plots recorded over $8-10$ years ( 8 years in $2000-S$ and $2000-O$ blocks, 9 years in 1999-S and 1999-O blocks, and 10 years in 1998-S and 1998-O blocks). Based on fire and storm-surge impacts, plots were in one of four groups: (i) unburned, (ii) burned, (iii) unburned+SS, and (iv) burned+SS. Burned referred to both prescribed burns (1998 and 2001) and nontargeted burns (2004). SS: Impacted by storm-surge caused by Hurricane Wilma in 2005.

there was no significant difference (K-W Test; $n=343, P=$ .251) in mean rank DBH between the trees killed in the 1st year and the trees killed in second or third year, suggesting that most of the large slash pine trees did not suffer mortality from fire. Three years after fire in these plots, the mean $( \pm$ SD) $\mathrm{DBH}$ of the dead trees $(11.4 \pm 6.6 \mathrm{~cm})$ was smaller than live trees $(12.8 \pm 5.7 \mathrm{~cm})$. 


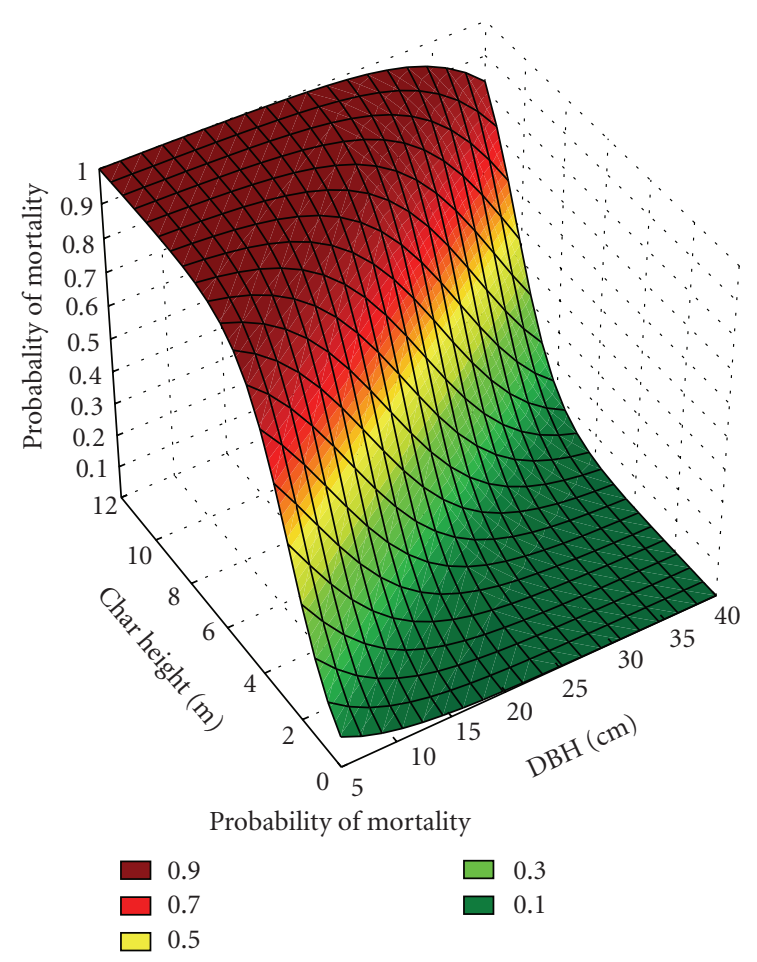

FIGURE 3: Response surface for logistic regression model for probability of 1-year post-fire tree mortality (Model 2) as a function of DBH and char height for slash pine (Pinus elliottii var. densa) after the experimental prescribed fires (1998-2000) in Big Pine Key, Florida. The number of live and dead trees used to develop the model was 2,849 and 681, respectively.

In the two blocks burned in 2001 (2000-O and 2000S), the status (live/dead) of trees was recorded only after 7years. These two blocks differed in understory conditions and time since last fire. However, plot-level mean percent mortality did not differ between $2000-\mathrm{O}(49.2 \%)$ and 2000 S (44.0\%) blocks. The best predictive model $\left(\chi^{2}=36.1\right.$; $P \leq .001)$ for predicting 7 year post-fire tree mortality also included $\mathrm{DBH}$, char height, and percent crown scorch as predictors (Table 4). However, the model had relatively low concordance $(C=0.768)$, suggesting that the predictive ability of tree size and immediate fire damage to the stem and crown declined over time.

3.2. Tree Mortality from Storm Surge. Five burned and two unburned plots located in low elevation $(<1 \mathrm{~m})$ areas were severely impacted by storm surge (Table 1 ). Cumulative pine tree mortality over 8-10 years was higher in storm surgeimpacted burned and unburned plots than in unimpacted burned and unburned plots, respectively. A negative exponential model was significant $\left(n=13 ; r^{2}=0.29 ; P<\right.$ $.05)$, suggesting that tree mortality in storm-surge impacted burned plots was relatively high (Figure 6). In unburned plots, however, a statistically significant negative correlation $\left(n=5 ; r^{2}=0.92 ; P<.001\right)$ between elevation and pine tree mortality suggested that the impact of storm surge was influenced by elevation. Mean ground elevation in the

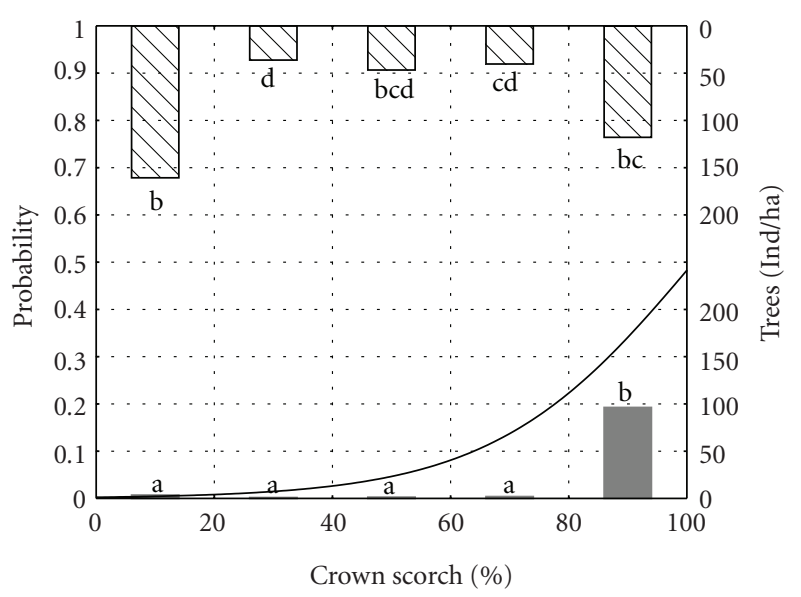

FIGURE 4: 1-year post-fire tree mortality probabilities predicted using logistic regression model as a function of percent crown scorch (Model-3) for slash pine (Pinus elliottii var. densa) after the experimental prescribed fires (1998-2000) in Big Pine Key, Florida. The number of live and dead trees used to develop the model was 2,870 and 680, respectively. Upright and hanging bars in the figure are the mean number of dead and live trees, respectively, in five crown scorch categories averaged over seven burned plots. The right $Y$-axis is scaled accordingly to represent the number of both dead and live trees. Different letters above/below the bar indicate significant differences in mean number of trees among percent crown scorch categories in burned plots $(n=7)$ (Kruskal-Wallis $H$ test) separately for live and dead trees, and between live and dead categories (Mann-Whitney $U$-test) within each scorch category.

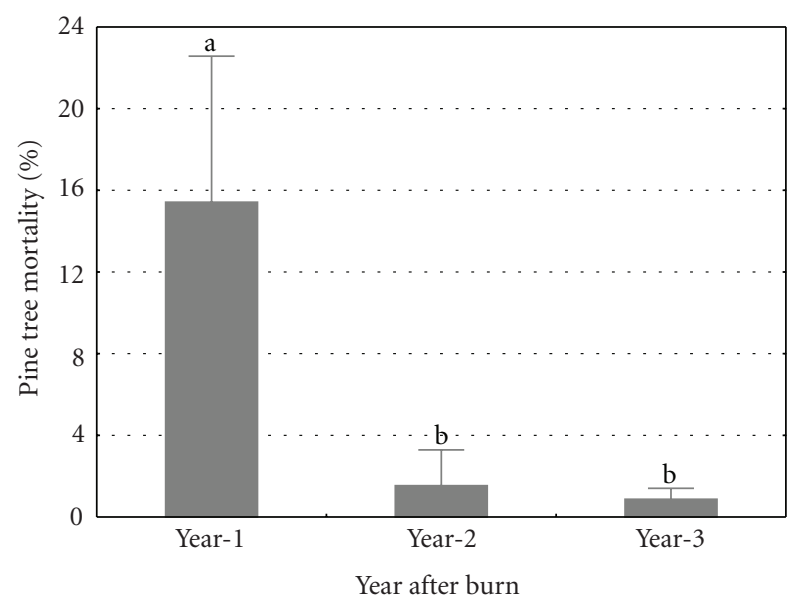

FIGURE 5: Mean ( \pm 1 Std. error) post-fire pine tree mortality percent in three consecutive years in experimental plots $(n=4)$ burned in 1998 in Big Pine Key. The different letters above the bars indicate significant differences in mortality between years.

impacted unburned plots $(0.793 \mathrm{~m})$ was significantly (Oneway ANOAVA; $\left.F_{1,3}=114 ; P=.002\right)$ lower than in the unimpacted unburned plots $(1.371 \mathrm{~m})$.

Storm surge tree mortality was size dependent. In unimpacted burned plots, the likelihood of tree mortality decreased with increasing DBH, whereas in surge-impacted burned plots, no such relationship was observed, suggesting 
that more trees in larger sized classes were killed by storm surge. Two unburned plots that were impacted by storm surge showed mixed results. While together they did not show a significant relationship between tree mortality and $\mathrm{DBH}$, one of them, 2000-S-C, which was close to the coast and was severely impacted, had tree mortality positively related with tree size.

3.3. Change in Stand Structure. Over a decade, stand structure was substantially influenced by fire and the storm surge event. Among four groups: (i) no burn and no storm surge (Unburn), (ii) burned but no storm surge (Burned), (iii) no burn but storm surge (Unburn-SS), and (iv) burned and storm surge (Burned-SS), the mean change in both basal area and stand diameter differed significantly (Oneway ANOVA; $\left.F_{3,14}=25.6 ; P<.001\right)$. In a majority of sites (15 of 18 experimental plots), there was a significant reduction in total basal area. Only three plots, 1999-S-C, 1999-S-W, and 2000-O-C plots, which were neither burned nor influenced by storm surge showed an increase in total basal area (Figure 7). The plots that were burned and severely impacted by storm surge had the greatest reduction in basal area. In these plots, mean stand diameter also decreased over the period (Figure 8). In contrast, mean stand diameter increased in the unflooded burned plots, as fire-induced tree mortality in those plots was mostly in small size classes. Size-selective mortality caused by fire and storm surge also affected the overall size distribution of pine trees in Big Pine Key pinelands. At both the beginning and end of the decadelong study, forest structure was characterized by inverse-J diameter distributions (Figure 9). However, the distribution curves differed significantly $\left(F_{3,11}=23.7 ; P=.0004\right)$ between the two surveys. The distribution curve for 2008 survey is flatter than the first survey, suggesting a decrease in the number of trees, particularly in smaller size classes. The reduction in number of trees was not uniform in all size classes, resulting in an obvious shift in the proportion of trees among size classes. The proportion of trees in small (5-10) and large $(>20 \mathrm{~cm})$ size classes decreased from $46.7 \%$ and $9.2 \%$ to $40.8 \%$ and $7.9 \%$, respectively, but increased from $44.2 \%$ to $51.4 \%$ in intermediate-sized $(10-20 \mathrm{~cm})$ trees.

\section{Discussion}

South Florida slash pine forest requires fire for its maintenance. Fire influences stand structure by killing vulnerable pine trees, promoting pine regeneration, regulating establishment and growth of hardwoods, and directing herb layer dynamics. In addition to fire, insect infestations and hurricanes are other disturbances that kill trees in southern Florida pine forests. The frequency and strength of these disturbances determine stand composition, particularly when their influences on tree mortality vary across different size classes.

Variation in fire intensity across the landscape depends on microtopography, prevailing weather conditions (e.g., wind speed and humidity), and fuel heterogeneity, and has a direct bearing on post-fire tree mortality. In the present

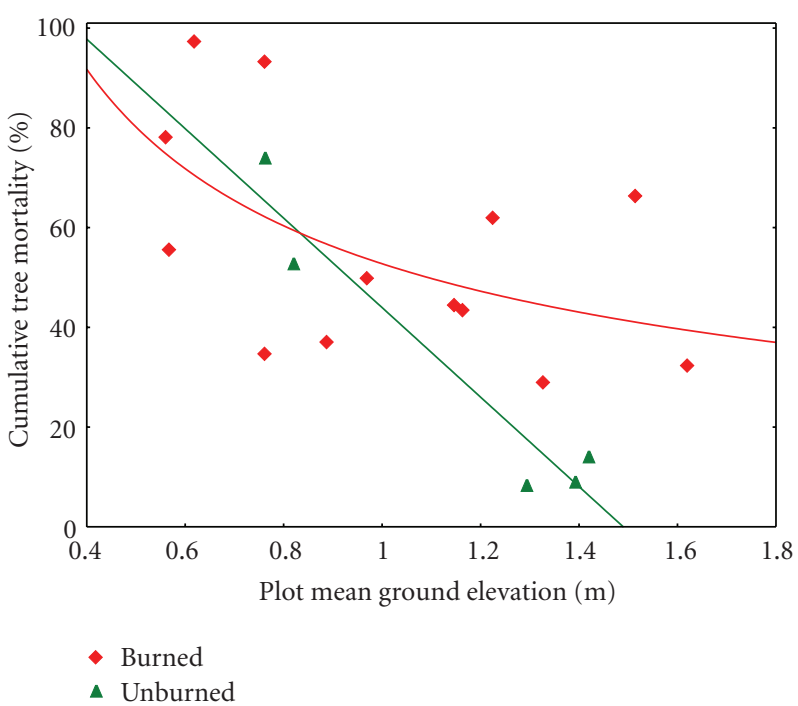

Figure 6: Cumulative pine tree mortality in relation to mean ground elevation in 18 stands. Two separate models were fit for burned and unburned plots. (i) Burned plots $(n=13): \mathrm{T}_{\mathrm{m}}$ $=52.7 * \mathrm{Elev}^{-0.60}$. (ii) Unburned plots $(n=5): T_{m}=133.7-$ $89.7 *$ Elev. $T_{m}=$ cumulative tree mortality.

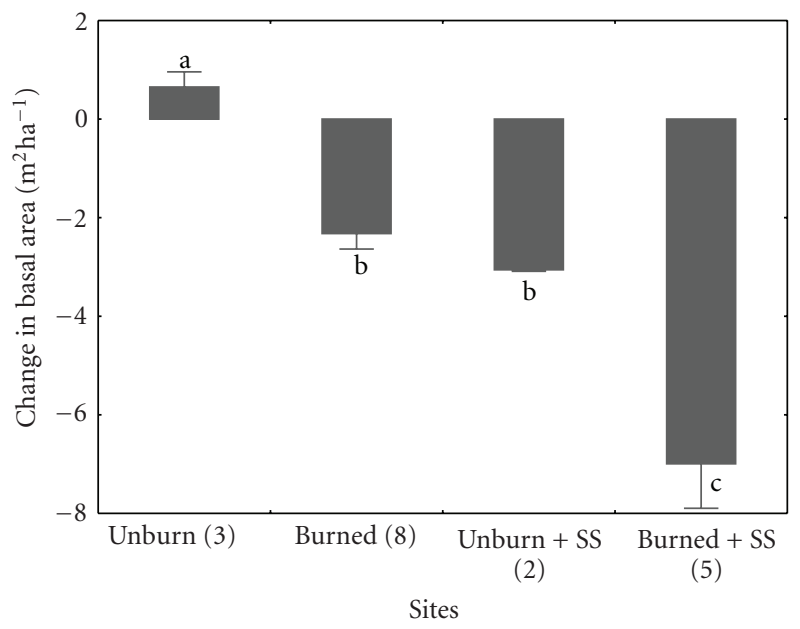

Figure 7: Change in mean $( \pm 1 \mathrm{SE})$ total basal area $\left(\mathrm{m}^{2} \mathrm{ha}^{-1}\right)$ in 4 groups of sites. Four groups were (i) No burn and no storm surge, (ii) Burned but no storm surge, (iii) No burn but storm surge, and (iv) Burned and storm surge. SS: Storm surge. Number of plots in each group is given in parenthesis. Different letters above/below the bar indicate significant differences (ANOVA; $P<.05$ ) between groups.

study, variation in fire-induced pine mortality among stands may be attributed to differences in stand age and fuel loads that influenced fire intensity. Previous work in Florida Keys pine forests showed that fuel loads, particularly surface fuels and mid-canopy palms, were positively related to fire intensity, signified by char height [26]. Char height of individual trees was an important predictor of post-fire tree mortality in the present study as well. In contrast, surface fuel consumption, which is also an indicator of fire severity, 


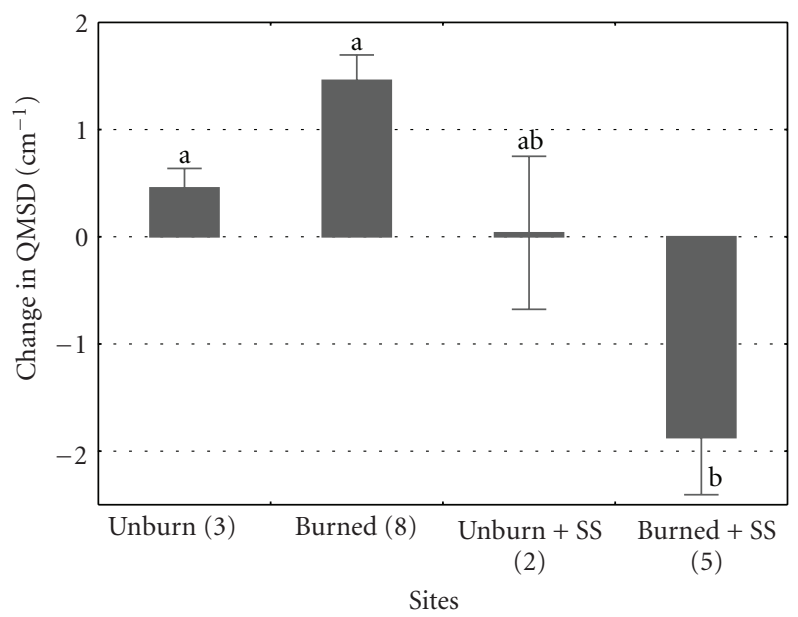

Figure 8: Change in mean ( $\pm 1 \mathrm{SE}$ ) quadratic mean stand diameter $(\mathrm{cm})$ in 4 groups of sites. Four groups were (i) No burn and no storm surge, (ii) Burned but no storm surge, (iii) No burn but storm surge, and (iv) Burned and storm surge. SS: Storm surge. Number of plots in each group is given in parenthesis. Different letters above/below the bar indicate significant differences (ANOVA: $P<.05)$ between groups.

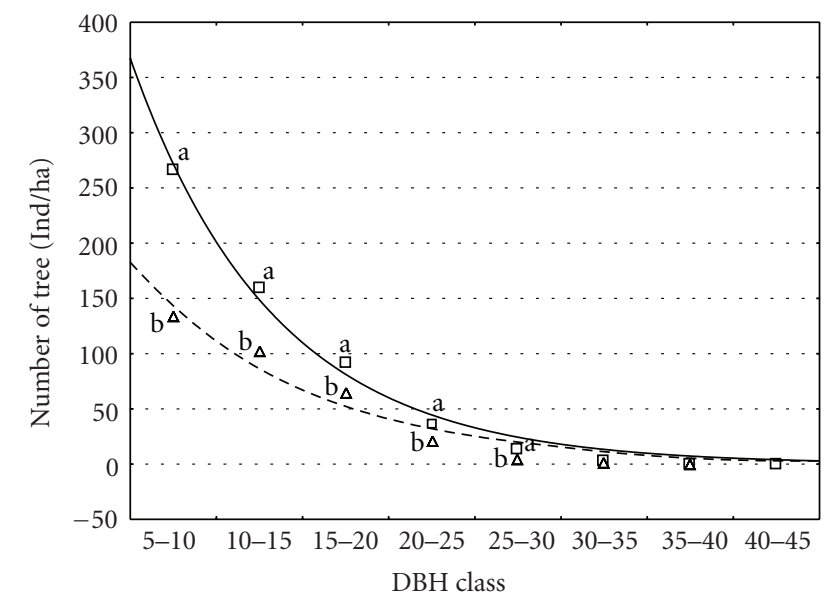

$$
\begin{array}{ll}
\square \text { Survey-1 }(1998-2000) & -\left(r^{2}=0.99\right) \\
\Delta \text { Survey-2 (2008) } & ---\left(r^{2}=0.943\right)
\end{array}
$$

Figure 9: Tree size distribution in experimental plots after two surveys, 1998-2000 and 2008. The models were fitted to the mean number of trees in each $\mathrm{DBH}$ class averaged over all 18 plots. The fitted models are (i) $T=116.6 * \exp ^{-\left(0.119^{*} X_{1}\right)}$, (ii) $T=$ $92.9 * \exp ^{-\left(0.101^{*} X_{1}\right)}$. T: Number of trees in a given dbh class. $X_{1}$ : mean DBH. Different letters above/below the _ indicate significant differences (ANOVA: $\mathrm{df}=1,34 ; P<.05$ ) in mean number of trees within each $\mathrm{DBH}$ class between two surveys.

was not significantly related to plot level mean percent tree mortality.

Even though understory fuel loads are generally higher in shrubby than open plots, we did not find significant effects of understory conditions on pine tree mortality. While it could partly be attributed to the limited power of statistical analysis caused by inadequate replicates, the results are in concurrence with earlier findings in Florida Keys pinelands. In these plots, fine scale fire intensity was negatively correlated with the quantity of hardwood shrubs mainly because these fuels were associated with moist environments, and therefore resistance to fire [26], which might have protected fine roots from burning. However, contrary to our expectation, season, which earlier had shown strong effects on fine scale fire intensity [26], was not significant in predicting stand level 1-year post-fire pine mortality. Our findings differed from the results of Menges and Deyrup [10], who found higher tree mortality in fall (October-December) burns than in fires in other seasons. In our study, three sites burned in December were considered winter burns, and mortality was not consistently different in these fires than in early summer burns. In other conifer forests, differences in tree mortality between burn seasons have been attributed to differences in fire intensity [33] or to physiological activity and carbohydrate storage [34]. Though South Florida slash pine trees are physiologically active in winter, radial growth slows or ceases early in the fall (Ross unpublished data), indicating differences in physiological activity between the two seasons. Moreover, effect of season may have mediated through char height and/or percent crown scorch, the indicators of fire intensity and severity, respectively. A study on fuel consumption has also shown that the direct effect of season on the consumption was low, and most of its effect was through char height [26]. The small number of fires, three winter and three summer burns, in our study might have also contributed to the lack of a statistically significant seasonal effect. But, the results do suggest that regardless of burn season, trees of similar size and identical stem and crown damage bear the same probability of mortality in the Florida Keys pine forests.

The likelihood that pine trees were killed by fire was strongly influenced by tree size (DBH). The greater fire resistance of trees with increasing diameter is attributed to increased insulation caused by thicker bark in large trees $[14,35]$. Our findings again differed from those of Menges and Deyrup [10], who found that DBH was a weak predictor of post-fire tree mortality, and inferred that DBH and bark thickness may be poorly related in their study area. Mean DBHs in Florida Keys were smaller than in the study of Menges and Deyrup, and that holds true even for longunburned ( $>30$ years) plots. In Lower Florida Keys, since likelihood of fire-induced tree mortality was higher in small dbh classes, the long-unburned plots also experienced as high percent mortality as did the short unburned ( $\leq 14$ years) plots, both burned in the same season in the year. The reason could be that the fires in this study were of relatively low to medium intensity. The inverse relationship that we found between DBH and tree mortality may also be explained by covariation with tree height. As DBH increases, so does tree height, increasing the distance between meristematic tissues in branches and the flame front [36]. This may explain why DBH was also negatively related to percent crown scorch in the present study. Our observation of a decrease in postfire mortality with increasing DBH in South Florida slash pine was consistent with findings from other pine species $[18,37-41]$. In contrast, our results for delayed mortality 
differed from studies of wildfires, where delayed mortality often occurs in larger $\mathrm{DBH}$ classes, possibly as a result of root damage $[11,42]$. In our low intensity prescribed fires, delayed mortality, particularly two and three years after fire, was very low. Approximately 94\% of fire-induced slash pine mortality occurred within one year, a pattern also observed by others $[9,10]$. Processes that lead to delayed post-fire mortality, for example, pathogenic attacks and increased water stress triggered by root damage, particularity in sites where fire is reintroduced after a long period of fire suppression [43], might not have crossed critical thresholds after the prescribed fires we studied.

Immediate crown and stem injuries and fire resistance mechanisms are important determinants of fire-induced tree mortality. Although researchers have emphasized measures of both foliage and stem damage as important predictors of tree mortality $[7,18]$, percent crown scorch has frequently been found to be the single best predictor of tree mortality [17]. In the present study, a model with percent crown scorch as the sole independent variable was highly significant (Table 4$)$. Trees that died suffered a large proportion $(>80 \%)$ of crown scorch. Nevertheless, even trees with $>80 \%$ crown scorch had $>50 \%$ chance of survival, suggesting that slash pine trees have the ability to survive severe crown scorch. The fate of trees with high levels of crown scorch depends on how well the buds are protected in tree crowns. In this study, buds might have been killed by severe scorching of foliage. In most individuals, however, buds did not succumb, probably because buds in slash pine are shielded from lethal effects of fire by long needles. In many conifers, the lower portions of crowns are less efficient in photosynthesis [11], and therefore scorching of that portion may not significantly reduce photosynthesis. Instead, scorching of lower crowns may help the trees by reducing the transpiration to cope with increased water stress after fire. Hence, in the present study, trees with even a small portion of the top crown intact or inflicted with light scorch after fire easily recovered from injury.

Stem damage from fire primarily involves injury to the cambium, which is measured indirectly in terms of stem charring. The depth of stem char relates positively with the degree of cambial injury and depends on the residence time of fire. Maximum char height or relative char height ( $\max$ char height in relation to tree height) is the representation of flame length or fire intensity. In our study, we did not measure tree height, but a model that included both char height and DBH was highly significant (Table 4). Nonetheless, the effects of these two variables were inversely related. The likelihood of tree mortality increased with increasing char height, but at the same char height, smaller trees were more likely to be killed (Figure 3 ). This suggests that mature slash pines are resistant to intense surface fire. Our finding that char height and DBH together predict post-fire tree mortality well is consistent with results of several other researchers $[6,17,37,39]$. Nonetheless, a full model that included tree size, and measures of both stem and foliage damages as predictors, was the best $(\mathrm{ROC}=0.911)$ in predicting post-fire tree mortality in Florida Keys pine forests, probably due to added predictive ability of percent crown scorch in small DBH classes.
Insect infestations and hurricane-associated events are known to cause additional pine mortality in post-fire years. In slash pine forests, infestation by Ips (pine engraver beetles) has been found to contribute to post-fire tree mortality [9, 10]. We did not study pest infestations after prescribed fire, but elevated post-fire tree mortality was observed in stormsurge impacted sites. Slash pines are considered resistant to wind damage [12], but they are sensitive to salinity stress, and their tolerance to salinity stress may vary with growth stage. In general, salt tolerance of nonhalophytic woody plants increases progressively with increasing age [44]. In our study, however, storm surge-caused pine mortality centered in large $\mathrm{DBH}$ classes suggested that large trees were particularly susceptible to salinity. Storm surge is a pulse disturbance [13]. After the surge, storm water gradually receded, but it is likely that ground water in the freshwater lens was affected for a long period thereafter. Driven mainly by long tap roots and the necessity of fulfilling a high transpiration requirement, large trees accessing the deeper ground water might have suffered from both water and salinity stress for an extended period-longer than small-sized trees.

In burned plots, the loss of small trees exclusively would cause a shift in the size structure of trees from a negative exponential (inverted J) distribution towards the unimodal size distribution. In our study, tree distribution pattern also exhibited a gradual shift (Figure 9), but the size distribution still retained the shape originally observed prior to the burns. In plots that experienced both fire and storm surge, however, a drastic change in stand structure occurred, resulting in a decrease in mean stand diameter. In contrast, plots that were burned but not impacted by the storm surge exhibited an increase in mean stand diameter. Such changes in mean stand diameter resulted from a contrast in sizeselective mortality initiated by fire and by storm surge. The effects of pulse events like storm surge on post-fire pine tree mortality could be additive, resulting from additional damage to morphological structures and physiological characteristics, or synergistic, particularly when fire modifies the susceptibility of trees to subsequent stresses. A continuous monitoring program designed to assess the interacting effects of prescribed fire and other disturbances would help to decouple their effects on tree mortality and stand structure.

\section{Conclusions}

Our results indicate that tree size $(\mathrm{DBH})$ and fire characteristics, expressed in terms of stem and crown damage (char height and percent crown scorch), are key determinants of fire-induced slash pine mortality. The study supports other research findings that large pine trees are resistant to damage from surface fire, which may be of practical importance for the use of prescribed fire to reduce the midstory cover while retaining the large trees. In pine forests, mature large trees are the source of cones necessary for continuing regeneration, and needles, a major component of the surface fuels necessary to conduct prescribed fire. This study did not directly assess secondary influences on slash pine mortality in subsequent years after fire, though 
most of the mortality observed a year after fire reveals that the secondary agents, for example, post-fire insect attacks were not important. This study included tree mortality in response to hurricane-associated storm surge. Our study adapted indirect analysis for evaluating the size-selective mortality pattern caused by fire and storm surge. However, their effects might have been confounded in our analysis, as we did not know the immediate prehurricane status of the trees or have real-time measurements of the depth or duration of salt water inundation. Some sites which we considered to be unimpacted by the storm surge might have been affected to some extent but was not noticeable during our study. Moreover, this study did not address synergistic effects of fire and storm surge, that is, whether earlier fires enhanced, inhibited, or did not modify the effects of subsequent storm surge on pine mortality. Nevertheless, this study was the first effort of its kind towards developing comprehensive, predictive models for fire-induced slash pine mortality in the Florida Keys. A cautious approach will need to be taken to generalize these models to other South Florida pine forests, as the topography, microclimate, and stand structure of pine forests in the Keys are different from those on the mainland, and fires in this study were only low to medium intensity. In addition, the statistical power of analysis was limited due to inadequate replicates in the experimental design, and the problems in carrying out the originally intended experimental burns, resulting in missing values for some treatments. Nevertheless, our findings of size-selective mortality caused by fire and storm surge have practical importance for the use of prescribed fire as a management tool in the future, when increased frequency and intensity of tropical storms combined with sea level rise may threaten the continued existence of Florida Keys pine forests.

\section{Acknowledgments}

The first phase (1998-2001) of this research was funded by the U.S. Department of the Interior Joint Fire Program (CA-1445-CA09-95-0112) and the second phase (1998) by US Fish and Wildlife Service (Interagency Agreement no. 401817N040. Michael Ross and Danielle Ogurcak were also partially supported by the US Department of Energy's Office of Science (BER) through the Coastal Center of the National Institute for Climatic Change Research at Tulane University. The authors thank Keqi Zhang, FIU, and The Nature Conservancy for LiDAR data, and National Key Deer Refuge for providing support to conduct this work. Jim Durrawachter (FMO) and his staff from Florida Panther National Wildlife Refuge conducted the treatment burns. They also thank Chris Borg (project manager), Elizabeth Bergh, Angela Forman, Sahara Moon Chapotin, Joanne Singfield, Jenny McCune, Jana Mott, Christie Whelan, Sarah Naylor, Hillary Colley, Dave Reed, and Pablo Ruiz who helped in the field during 1998-2001. Tina Henize, Dennis Henize, Marianna Bradley, Mark Knowles, and Wendy Miller worked as field assistants and collected data during 20062008 field work. This is SERC Contribution no. 471.

\section{References}

[1] H. H. Biswell, Prescribed Burning in California Wildland Vegetation Management, University of California Press, Berkeley, California, USA, 1989.

[2] N. T. Welch and T. A. Waldrop, "Restoring table mountain pine (Pinus pungens lamb.) communities with prescribed fire: an overview of current research," Castanea, vol. 66, no. 1-2, pp. 42-49, 2001.

[3] R. J. Mitchell, J. K. Hiers, J. J. O’Brien, S. B. Jack, and R. T. Engstrom, "Silviculture that sustains: the nexus between silviculture, frequent prescribed fire, and conservation of biodiversity in longleaf pine forests of the southeastern United States," Canadian Journal of Forest Research, vol. 36, no. 11, pp. 2724-2736, 2006.

[4] J. S. Glitzenstein, W. J. Platt, and D. R. Streng, "Effects of fire regime and habitat on tree dynamics in north Florida longleaf pine savannas," Ecological Monographs, vol. 65, no. 4, pp. 441476, 1995.

[5] M. E. Harmon, "Survival of trees after low-intensity surface fires in Great Smoky Mountains National Park," Ecology, vol. 65, no. 3, pp. 796-802, 1984.

[6] C. Hély, M. Flannigan, and Y. Bergeron, "Modeling tree mortality following wildfire in the southeastern Canadian mixed-wood boreal forest," Forest Science, vol. 49, no. 4, pp. 566-576, 2003.

[7] J. F. Fowler and C. H. Sieg, "Post-fire mortality of ponderosa pine and douglas-fir: a review of methods to predict tree death," General Technical Report RMRS-GTR-132, Forest Service, Rocky Mountain Research Station, USDA, Fort Collins, Colo, USA, 2004.

[8] L. Kobziar, J. Moghaddas, and S. L. Stephens, "Tree mortality patterns following prescribed fires in a mixed conifer forest," Canadian Journal of Forest Research, vol. 36, no. 12, pp. 32223238, 2006.

[9] W. N. Dixon, J. A. Corneil, R. C. Wilkinson, and J. L. Foltz, "Using stem char to predict mortality and insect infestation of fire-damaged slash pines," Southern Journal of Applied Forestry, vol. 8, no. 2, pp. 85-88, 1984.

[10] E. S. Menges and M. A. Deyrup, "Postfire survival in south Florida slash pine: interacting effects of fire intensity, fire season, vegetation, burn size, and bark beetles," International Journal of Wildland Fire, vol. 10, no. 1, pp. 53-63, 2001.

[11] S. M. Hood, S. L. Smith, and D. R. Cluck, "Delayed conifer tree mortality following fire in California," General Technical Report PSW-GTR-203, USDA Forest Service, Pacific Southwest Research Station, Albany, Calif, USA, 2007.

[12] W. J. Platt, B. Beckage, R. F. Doren, and H. H. Slater, "Interactions of large-scale disturbances: prior fire regimes and hurricane mortality of savanna pines," Ecology, vol. 83, no. 6, pp. 1566-1572, 2002.

[13] M. S. Ross, J. J. O’Brien, R. G. Ford, K. Zhang, and A. Morkill, "Disturbance and the rising tide: the challenge of biodiversity management on low-island ecosystems," Frontiers in Ecology and the Environment, vol. 7, no. 9, pp. 471-478, 2009.

[14] K. C. Ryan and E. D. Reinhardt, "Predicting postfire mortality of seven western conifers," Canadian Journal of Forest Research, vol. 18, no. 10, pp. 1291-1297, 1988.

[15] G. E. Hengst and J. O. Dawson, "Bark properties and fire resistance of selected tree species from the central hardwood region of North America," Canadian Journal of Forest Research, vol. 24, no. 4, pp. 688-696, 1994.

[16] C. E. Van Wagner, "Height of crown scorch in forest fires," Canadian Journal of Forest Research, vol. 3, pp. 373-378, 1973. 
[17] J. G. Wyant, P. N. Omi, and R. D. Laven, "Fire induced tree mortality in a Colorado ponderosa pine/Douglas-fir stand," Forest Science, vol. 32, no. 1, pp. 49-59, 1986.

[18] C. W. McHugh and T. E. Kolb, "Ponderosa pine mortality following fire in northern Arizona," International Journal of Wildland Fire, vol. 12, no. 1, pp. 7-22, 2003.

[19] J. M. Varner III, D. R. Gordon, F. E. Putz, and J. K. Hiers, "Restoring fire to long-unburned Pinus palustris ecosystems: novel fire effects and consequences for long-unburned ecosystems," Restoration Ecology, vol. 13, no. 3, pp. 536-544, 2005.

[20] D. L. Peterson, "Crown scorch volume and scorch height: estimates of post-fire tree condition," Canadian Journal of Forest Research, vol. 15, pp. 596-598, 1985.

[21] J. M. Saveland and L. F. Neuenschwander, "A signal detection framework to evaluate models of tree mortality following fire damage," Forest Science, vol. 36, no. 1, pp. 66-76, 1990.

[22] T. T. Kozlowski, Responses of Woody Plants to Flooding and Salinity, Tree Physiology Monograph 1, Heron Publishing, Victoria, Canada, 1997.

[23] J. R. Snyder, A. Herndon, and W. B. Robertson, "South Florida rocklands," in Ecosystems of Florida, R. L. Myers and J. J. Ewel, Eds., pp. 230-277, University of Central Florida Press, Orlando, Fla, USA, 1990.

[24] P. C. Carlson, G. W. Tanner, J. M. Wood, and S. R. Humphrey, "Fire in key deer habitat improves browse, prevents succession, and preserves endemic herbs," The Journal of Wildlife Management, vol. 57, no. 4, pp. 914-928, 1993.

[25] J. R. Snyder, M. S. Ross, S. Koptur, and J. P. Sah, "Developing ecological criteria for prescribed fire in south Florida pine rockland ecosystems," Open File Report OF 2006-1062, US Geological Survey, 2005.

[26] J. P. Sah, M. S. Ross, J. R. Snyder, S. Koptur, and H. C. Cooley, "Fuel loads, fire regimes, and post-fire fuel dynamics in Florida Keys pine forests," International Journal of Wildland Fire, vol. 15, no. 4, pp. 463-478, 2006.

[27] H. Liu and E. S. Menges, "Winter fires promote greater vital rates in the Florida keys than summer fires," Ecology, vol. 86, no. 6, pp. 1483-1495, 2005.

[28] D. Wade, J. Ewel, and R. Hofstetter, "Fire in south Florida ecosystems," General Technical Report SE-17, USDA Forest Service, Southeastern Forest Experiment Station, Asheville, NC, USA, 1980.

[29] J. R. Snyder, "Fire regimes in subtropical south Florida," in Proceedings of the Tall Timbers Fire Ecology Conference No. 17-High Intensity Fire in Wildlands: Management Challenges and Options, May 1989, pp. 303-319, Tall Timbers Research Station, Tallahassee, Fla, USA, 1991.

[30] USDI-NPS (US Department of Interior, National Park Service), Fire Monitoring Handbook, National Interagency Fire Center, US Department of Interior National Park Service, Boise, Ind, USA, 2001.

[31] D. W. Hosmer and S. Lemeshow, Applied Logistic Regression, John Wiley \& Sons, New York, NY, USA, 2nd edition, 2000.

[32] W. Robertson and K. Zhang, "Airborne LIDAR data and digital elevation models of Big Pine Key, Florida," Report, The Nature Conservancy, Florida Keys Program, Summerland Key, Fla, USA, 2007.

[33] M. G. Harrington, "Predicting Pinus ponderosa mortality from dormant season and growing season fire injury," International Journal of Wildland Fire, vol. 3, no. 2, pp. 65-72, 1993.

[34] W. G. Thies, D. J. Westlind, and M. Loewen, "Season of prescribed burn in ponderosa pine forests in eastern Oregon: impact on pine mortality," International Journal of Wildland Fire, vol. 14, no. 3, pp. 223-231, 2005.
[35] M. A. Pinard and J. Huffman, "Fire resistance and bark properties of trees in a seasonally dry forest in eastern Bolivia," Journal of Tropical Ecology, vol. 13, no. 5, pp. 727-740, 1997.

[36] C. E. Van Wagner, "Height of crown scorch in forest fires," Canadian Journal of Forest Research, vol. 3, pp. 373-378, 1973.

[37] J. C. Regelbrugge and S. G. Conard, "Modeling tree mortality following wildfire in Pinus ponderosa forests in the central Sierra Nevada of California," International Journal of Wildland Fire, vol. 3, no. 3, pp. 139-148, 1993.

[38] S. L. Stephens and M. A. Finney, "Prescribed fire mortality of Sierra Nevada mixed conifer tree species: effects of crown damage and forest floor combustion," Forest Ecology and Management, vol. 162, no. 2-3, pp. 261-271, 2002.

[39] J. L. Beverly and D. L. Martell, "Modeling Pinus strobus mortality following prescribed fire in Quetico Provincial Park, northwestern Ontario," Canadian Journal of Forest Research, vol. 33, no. 4, pp. 740-751, 2003.

[40] E. Rigolot, "Predicting postfire mortality of Pinus halepensis Mill. and Pinus pinea L.," Plant Ecology, vol. 171, no. 1-2, pp. 139-151, 2004.

[41] T. L. Keyser, F. W. Smith, L. B. Lentile, and W. D. Shepperd, "Modeling postfire mortality of ponderosa pine following a mixed-severity wildfire in the Black Hills: the role of tree morphology and direct fire effects," Forest Science, vol. 52, no. 5, pp. 530-539, 2006.

[42] J. Barlow, C. A. Peres, B. O. Lagan, and T. Haugaasen, "Large tree mortality and the decline of forest biomass following Amazonian wildfires," Ecology Letters, vol. 6, no. 1, pp. 6-8, 2003.

[43] J. J. O’Brien, J. K. Hiers, R. J. Mitchell, J. M. Varner III, and K. Mordecai, "Acute physiological stress and mortality following fire in a long-unburned longleaf pine ecosystem," Fire Ecology. In press.

[44] M. C. Shannon, C. M. Grieve, and L. E. Francois, "Wholeplant response to salinity," in Plant_Environment Interactions, R. E. Wilkinson, Ed., pp. 199-244, Marcel Dekker, New York, NY, USA, 1994. 

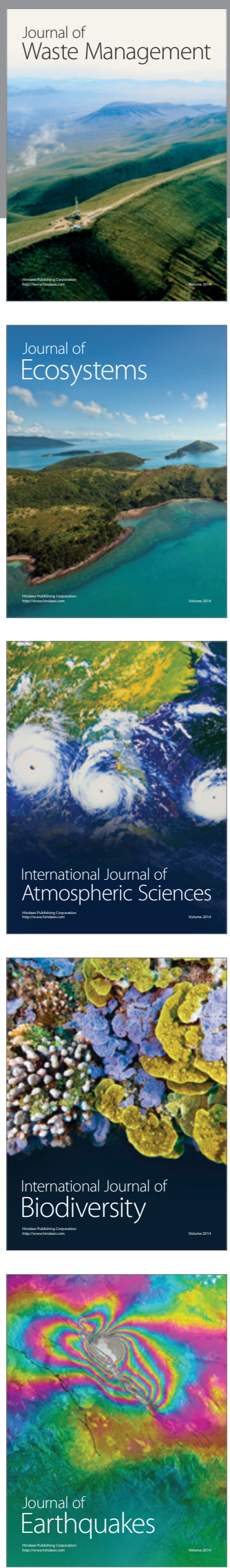
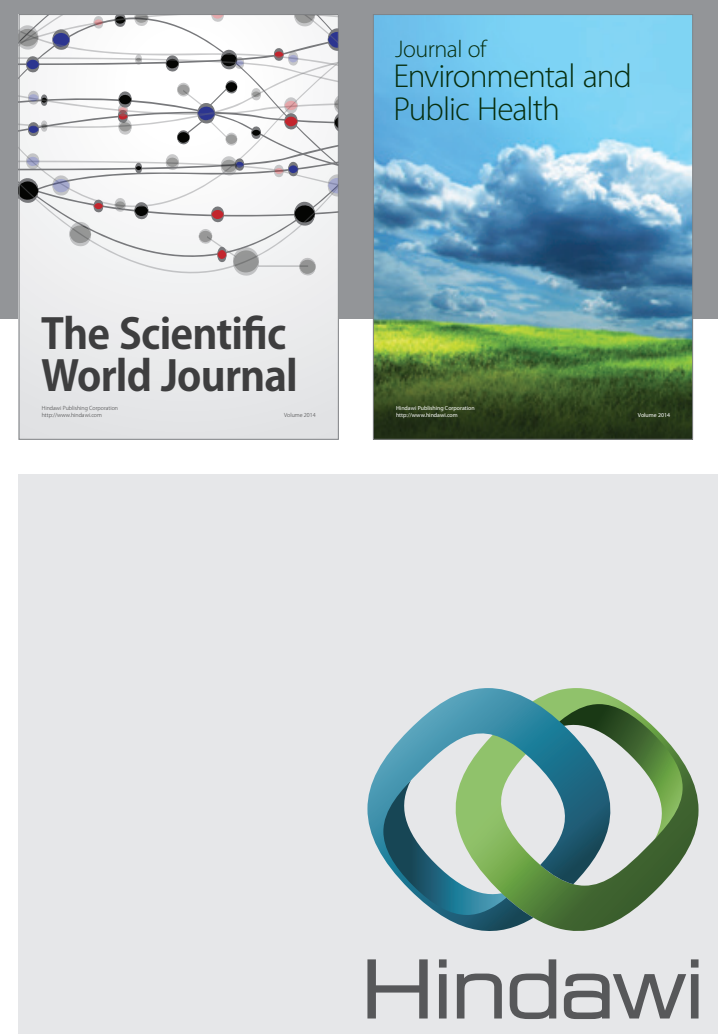

Submit your manuscripts at

http://www.hindawi.com
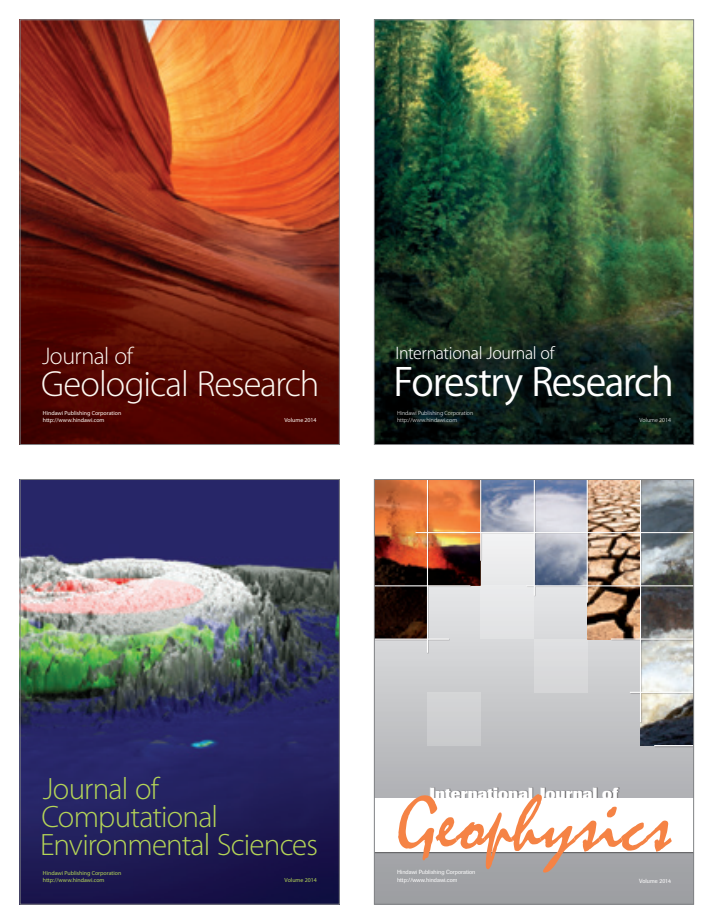
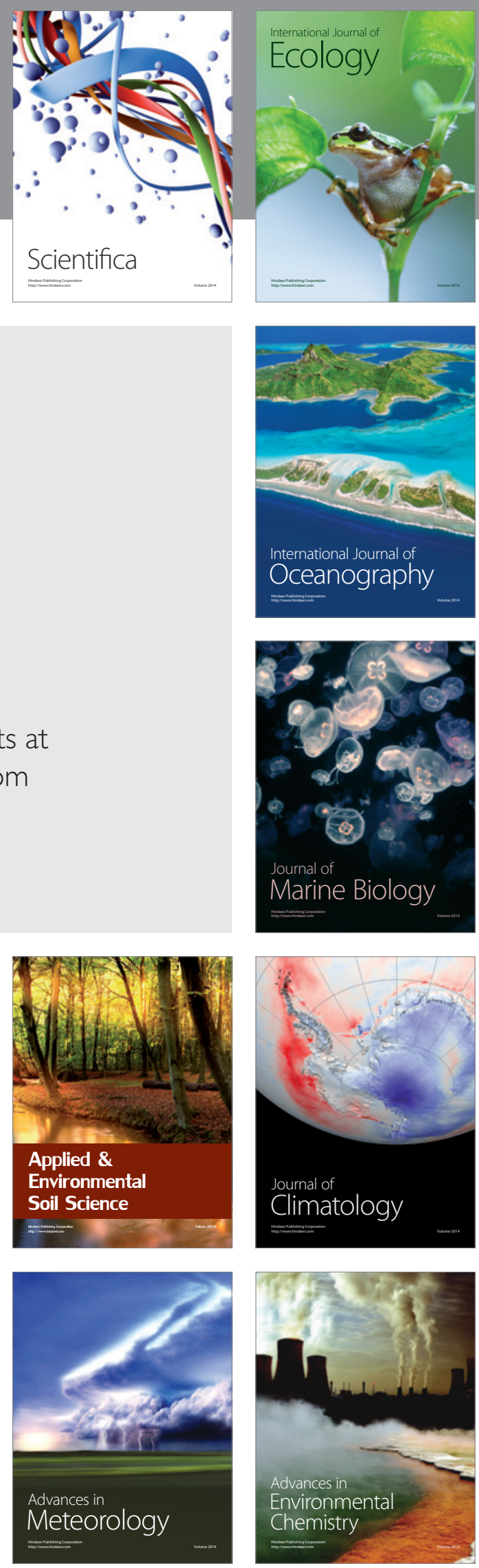